\title{
The Application of Third Party Guarantee in Structuring Șukūk in the Islamic Capital Market: A Preliminary Literature Survey
}

\author{
Chaibou Issoufou \\ Senior Lecturer, Department of Islamic Finance, Universiti Kuala Lumpur (UniKL) Business School (UBIS) \\ Email: issoufou@unikl.edu.my \\ Umar A. Oseni \\ Associate Professor, Department of Civil Law, Faculty of Law, International Islamic University Malaysia \\ Email: umaroseni@iium.edu.my
}

Doi:10.5901/mjss.2015.v6n5p130

\begin{abstract}
In the Islamic capital market, the șukūk (Islamic investment certificates) segment is considered by key stakeholders in the Islamic financial services industry as the most vibrant segment in the global Islamic financial system. This paper provides a preliminary literature survey on the application of third party guarantee in Islamic capital market with specific reference to sukük transactions. The methodology adopted in this study leverages on the dynamics of comparative jurisprudential analysis of the different schools of thought in Islamic law from the classical to the modern jurists. Though this aspect of Islamic capital market is relatively in its infancy stage of development, the Islamic financial services industry is fraught with diverse practices where a perceptible disconnect is noticed between juristic ideals and practical application of third party guarantee in șukuk structuring. Therefore, the paper finds that though the use of third party guarantee is permissible in Islamic capital market, there is however a proviso which must be adhered to - the voluntary nature of the guarantee. The guarantee should be provided without charging any fee, and this is applicable in commonly used sukuk products such as șukūk al-ijārah, șukūk al-mudārabah, and șukūk al-istișnā'. It is however permissible to impose a compensatory fee in șukūk al-istișna ' in the case of failure to deliver the subject matter of the contract on the due date and the contractee has suffered a damage.
\end{abstract}

Keywords: third party guarantee, Islamic capital market, șukūk market, Islamic finance

\section{Introduction}

The operation of third party guarantee exists in almost all advanced jurisdictions, and it is having an increasing presence in the Islamic capital market, especially in șukukk transactions. Third party guarantee is of paramount importance in economic and social objectives, the principal ones being the protection of small, unsophisticated investors, maintaining confidence and stability within the financial sector, and the acceleration of failure resolution strategies in cases where an institution fails. In spite of this overarching relative importance of the concept, most of the available studies on third party guarantee in Islamic law concentrate more on the guarantee of debts. The classical Muslim jurists unanimously agree that any guarantee is voluntary in order to facilitate dealings among Muslims. However, only a few materials are available on the subject of third party guarantee in the Islamic capital market pertaining to sukūk. The Islamic capital market is one that is free from Islamically prohibited elements such as usury (ribā), gambling (maysir) and uncertainty (gharār) (McMillen, 2006; Hassan, Kayed \& Oseni, 201).

The third party guarantee and its operation is based on the principle of mutual consent guaranteed between investors. From the perspective of Islamic law, the "third party" is referred to as a person who is not involved with the investment and has no relationship with the investors, but who will be a guarantor for any loss that may occur in relation to the principal amount or profit realisable from the investment. The operation of third party guarantee in the Islamic capital market, particularly in the șukuk segment is relatively new compared to the conventional third party guarantee model which is rooted in the economic, capital market and banking system since 1829 in New York State (USA) when it was introduced (Fres-Felix, 1991: 7). Therefore, this makes a case for a research in this area in search for a new model of guarantee in the Islamic capital market. This preliminary analysis will provide a better grasp of the proper concept of third party guarantee and its application in the Islamic capital market. This study is significant as it explores carefully selected classical and modern studies on the application of third party guarantee in Islamic law. This unique approach to the study of third party guarantee provides a preliminary appreciation of 
the subject matter within the context of modern developments in the Islamic financial services industry.

With the increasing expansion of the Islamic financial products and services beyond its original base, many jurisdictions across the world now explore the numerous opportunities provided by the Islamic capital market products such as șukük. Different types of șukük are being used in the Islamic financial services industry based on the endorsement of fourteen different types of șukuk by the Accounting and Auditing Organisation for Islamic Financial Institutions (AAOIFI), an international-standard setting body in the industry (Khaleq \& Richardson, 2006; Maurer, 2010). Therefore, in order to complement the existing efforts in developing the Islamic capital market and ensure the products being offered are not only Shar'`'ah-compliant but also conventionally competitive, this study explores the nature of third party guarantee in Islamic law and its application in the Islamic capital market with particular reference to șukukk. This is because șukukk investment is a major milestone for the provision of capital for long-term investments that conform with the principles of Islamic law (Abdel-Khaleq \& Richardson, 2006).

Through the instrumentality of a literature survey, this study investigates the practice of the Islamic capital market with a special focus on the third party guarantee in șukūk, such as șukūk al-ijärah (lease-based investment certificates), șukūk al-mudārabah (trust partnership investment certificates) and șukūk al-istișnā' (manufacturing contract investment certificates). The modern Islamic capital market is still facing a major challenge relating to the extent of permissibility of third party guarantee to promote commercially viable șukük products. The literature survey reveals that the underlying principle of any guarantee in Islamic law is that it is voluntary, wherein a guarantor should not take any benefit from it, whether it is a financial benefit or otherwise. However, there seems to be a perceptible disconnect between the views of the classical Muslim jurists and contemporary practices in the Islamic capital markets, particularly in the structuring of șukūk transactions.

\section{The Meaning of Guarantee in Islamic Law}

From the juristic analyses, several meanings are attributed to the word "guarantee" (kafälah). According to Shāfi'i jurists, it refers to an undertaking or commitment to a right or debt that exists under another party's obligation, or to bring a guaranteed asset or guaranteed person who must be present at a specific time in a specific place face to face (al-Khatib, n.d.: 37; al-Haitami, 2001: 294; al-Yamani, 2000: 303). From these definitions, one can deduce that guarantee is a combined commitment between the guarantor and the guaranteed person in which both parties are liable for the right or debt that is guaranteed, until it is settled. Furthermore, Māliki jurists are of the view that it is an obligation that one party has taken towards the right of the other party. In other words, the guarantor has taken upon himself the right of the creditor in respect of which both the guarantor and guaranteed person are responsible (Al-Dasuqi, 1996: 537; Ulaish, 2003: 129). According to the Mālikī jurists, a guarantee contract cannot exempt the guaranteed person from the liability of the guaranteed asset (al-'Ihsā' '̄i, 1995: 22-23).

The Hanbali jurists consider the guarantee contract as a joint obligation of the guarantor and guaranteed person in the commitment that exists over the guaranteed party. Therefore, the creditor's right becomes the obligation of both parties. The owner of the right can henceforth claim from either the guarantor or the guaranteed party (Ibn Qudamah, n.d.: 590; al-Bahūtĩ: 2003: 242-243). The Hanbali jurists define guarantee as the combined responsibilities of the guaranteed person and the guarantor over the guaranteed asset where both parties become liable for the asset (al-Najar, 1996: 308).

The Hanafi jurists on their part define the guarantee contract as a joint obligation of the guarantor and the guaranteed party (principal debtor) in the claim of the debt only. The creditor can claim the debt from both parties. Nevertheless, he has no right to request payment of the debt from the guarantor; its payment is obliged only on the guaranteed person (Al-Sarakhsī, 2001: 194; al-Kalībūlī, 1998: 172; Ibn al-Sā 'Ātī, 2005: 439). Based on this Ḥanafî jurists' definition of guarantee, it is clear that the guarantor is only required to secure the debt, not to pay it. Its payment falls under the liability of the guaranteed person. This is a clear departure from the earlier juristic arguments presented above.

From the above definitions of guarantee from the four major Sunni schools of thought, it can be observed that the majority of Muslim jurists (Shāfí ${ }^{‘} \overline{1}$, Mālikī and Ḥanbalī jurists) contends that guarantee is a combined obligation of a right between the guarantor and the guaranteed party. In claiming his right, the creditor is entitled to claim from either the guarantor or the guaranteed party, as long as the financial right is yet to be settled. By looking at the definitions given by them, the guarantee contract does not absolve the guaranteed party from his liability. Thus, the obligation is binding on both the guarantor and the guaranteed party until the debt obligation is settled. However, according to the Hanafi's definition of guarantee, the guarantor is only liable to make the debtor pay the debt guaranteed by him. Thus, the creditor has only the right to demand the debt from the guarantor, but has no right to demand payment from him. Hence, the definition of guarantee by the majority of Muslim jurists is preferable and more appropriate to the contemporary practice of Islamic finance. This is also similar to the practice in conventional commercial guarantee where the guarantor is obligated to pay the debt of debtor at maturity (Henkel, 
2014).

From the foregoing, according to the definitions given by Muslim jurists, the contract of guarantee is neither a sale contract nor a transfer of debt contract. This is because when the terms and conditions of a sale contract have been concluded and ownership is transferred, only the buyer takes the responsibility for the sold item. In a transfer of debt contract, when terms and conditions of the contract are fulfilled, only the transferee is responsible for the transferred item, the transferer is free from any obligation or liability. This means that in the sale contract and transfer of debt contract only one party is bound by the contract, while in the guarantee contract both the guarantor and the guaranteed person are bound by the right that is guaranteed. (Al-Dasūqī, 2003: 537).

Furthermore, contemporary Muslim scholars, such as al-Zuhailī (2006: 15), define guarantee as an obligation to compensate a person financially due to the damage or loss that may be incurred to him from the act of another person. His definition is comprehensive as it can cover any compensation, be it financial or otherwise. Mustapha alZarqā (1997) defines guarantee as an act to undertake financial compensation for damage that may occur to another party. Besides, Article 612 of Majallah al-ahkäm al-'adliyyah defines guarantee as: "The addition of an obligation to an existing obligation in respect of the demand for a particular thing. That is, it is a contractual obligation where someone joins another person and binding himself through an undertaking to meet the obligation which accrues to that other person". This includes self-guarantee, debt or tangible asset (Tyser, 1980: 90-91; al-Lubnānī, 1920: 333; Haidar, 2003: 724). Therefore, both parties are liable for the thing that is undertaken to be guaranteed until its settlement is effected by one of them.

It is thus clear that the Islamic legal perspective of a guarantee represents a legal undertaking by a person of an obligation due to another to pay or compensate a financial value or physical value for a damage or loss that may occur to a third party. It is pertinent to note that the definition of guarantee by the classical jurists is not limited to debt guarantee.

In a similar vein, the contemporary scholars' definition is not confined to compensation for financial loss to the other party.

As a result, it can be observed that the definitions of guarantee by classical and contemporary Muslim scholars are not limited to debt guarantee, but generally include any compensation, either financial or physical, for any loss or damage that may occur to a person or property.

\section{The Nature of Third Party Guarantee in Islamic Law}

Muslim jurists such as Ibn Rushd (1985), Al- Qarāfĩ (2001), Ibn Al- Sā 'ātī (2005) and Ibn Qudāmah (n.d.), as well as Al-Humāmah Nizām (2000), discussed the types of guarantee, and the view of scholars pertaining to guarantee and when the guarantor can demand that the guaranteed party refunds what he is owing. They also highlight the rule of guarantee in financial matters by extensively discussing matters relating to guarantee in commercial transactions and its permissibility, including whether the subject matter is known or unknown, forms of guarantee and the extent to which it is valid. This is in addition to its rules in Islamic law, especially its concept and rule in the Qur'än, the Sunnah and ' 'ijmä', as well as the issue of guarantee in debts and services. They also discuss guarantee in lease contracts (ijärah), particularly in such matters relating to the appropriate time for the lessee to guarantee the leased asset. Their analysis on guarantee focused on general matters without further elaboration on guarantee in financial matters. However, this can help to conceptualise guarantee and its role in contemporary Islamic finance law.

On the other hand, modern scholars such as Al-Khafîf (n.d.), Al-Sālūs (1986), Al-Shubailī (2005), Musā (2008) and Jubar (2003) discussed guarantee from both the Islamic and civil law perspectives, especially the use of legal guarantee in debts, services and commercial matters. They discussed guarantee in investment accounts and how the Islamic bank guarantees customers' accounts in customer-banker relationships. They also highlight third party guarantee in banking activities and discussed the different points of view of scholars from the Islamic legal perspective. They extended their discussion to the concept of guarantee, types of guarantee, and the extent to which it is permissible in Islamic law and its conditions, as well as the form by which it is contracted. They also discussed guarantee in financial matters and highlight the approaches of scholars on this issue. Other issues discussed include guarantee in debt and the right of guarantor to claim what he has paid on behalf of the debtor in case the payment is made by the guarantor with or without the debtor's permission. Their approach is relevant to a more comprehensive study of the modern application of guarantee in the Islamic financial services industry. However, Al-'Ajulūnī (2008: 299-301), Bek (1936: 183-198), Al-Khayāṭ \& Al-'Ayādī (2004) added another dimension to the conceptual analysis of guarantee. In their individual unique manner, they discussed guarantee in debt and the use of multiple guarantors to debt. They also highlighted the applicable ruling on guarantee in case of the death of the principal debtor or guarantor, deferred and instant debt, and the time period within which the guarantor is to be discharged from the legal guarantee. They examine the banking fatäwa pertaining to guarantee and the use of legal guarantee in muräbahah sale. Even though their analyses focus on banking guarantee, the period of contract of guarantee as 
well as charging of a fee on guarantee, the conceptual basis of their comprehensive analyses provides a good framework for the discussion on the permissibility of charging fees on guarantee.

From the perspective of contemporary Islamic investment accounts, al-Mișrī (2009) examined guarantee of investment accounts and argued that the bank should guarantee them for investors. In this regard, he examined the opinions of Muhammad Bāqir and Sāmī Ḥasan pertaining to guarantee of customers' deposit accounts and investment accounts. He refuted their opinions and highlighted the opinions of classical scholars on guarantee and identified when the guarantor may benefit from the investment account. He extends his discussion of guarantee by permitting it with the charging of a fee, but without further elaboration on the subject. In addition, al-Mișrī (2009) further gave a new interpretation for the legal maxim: "Fee and guarantee are not combined," and discussed the approaches of jurists to this legal maxim. He contended that in a situation where a lessee is requested to pay the rent and the guarantee fee, it might not be appropriate to pay such rent and the guarantee fee for the leased item at the same time. This new interpretation of legal maxim has far reaching implications on the nature and operation of investment accounts in the modern Islamic financial services industry, particularly in jurisdictions such as Malaysia, that have introduced new rules for Islamic investment account and Islamic deposit account as regulated under the Islamic Financial Services Act 2013 (Act759).

\section{Application of Third Party Guarantee in the $S u k \bar{u} k$ Market}

While focusing on debt-based transactions, it will be interesting to consider how a legal guarantee is applied, particularly in the Islamic capital market. Abdul Mawjūd, et al (2002) discussed the contract of legal guarantee in debt and provided a comparative analysis on the definition of guarantee from the views of the four Sunni schools. The interesting part of their work is the discussion on a legal guarantee against market misrepresentation (damän aldark) and its dynamics within the contemporary Islamic banking industry. Damān al-dark is a form of legal guarantee that the subject matter of a contract is unencumbered. They highlighted the contemporary practice of guarantee in conventional banking and Islamic banking and for investment funds, the differences between the two practices regarding the types of investments and investors. Their contribution is useful in understanding the basic concept and principles of guarantee in conventional, Islamic and investment banking. From the perspective of specific Sharī‘ah-compliant modes of financing, Al-Kāsānī (2005) discussed a situation when a guarantor can return to a guaranteed person for a refund. He further discussed mudarabah, and the guarantee of principal amount of muḍärabah capital provided by the rabb al-māl. Al-Nawawī (2000) and al-Bābartī al-Hanafĩ (2007) also discussed the use of guarantee in mudärabah and ijärah contracts, though their works are limited to classical mud̄arabah and ijärah. Similar analyses are found in related studies by 'Abū Ghuddah (1998), 'Abū Sulaymān (1992), and Salām (1984). These classical analyses serve as a good basis for the modern conceptualisation of șukūk al-mudärabah and șukūk al-ijärah.

\subsection{Studies on Șukuk without Third Party Guarantee}

With a focus on Islamic capital market products, al-Qarah Dāghì (2004) discussed the definition of șukūk al-ijārāh and its unique peculiarities. He also discussed the rules of leasing in Islamic law and the differences between șukuk and bonds. He argued that the former is based on risk sharing while the latter is based on risk transfer. In conventional bonds, the principal amount invested is guaranteed plus the interest. His discussion also covers the guarantee of the principal investment in șukuk al-ijärah or sukūk al-mudärabah without any negligence or transgression, which is forbidden in Islamic law (al-Qarah Dāghī, 2004). The resolution of the Islamic Fiqh Academy of the Organisation of Islamic Cooperation (OIC) on șukūk al-ijärah states that it is impermissible for the issuer of sukukk or the manager to guarantee the original price of the șukuk or any profit. However, if the leased asset is destroyed completely or partially, the liability (ghurmuhā) is on the sukūk holders (Majma' al-Fiqh al'Islamī, 2004).

Al-Samirīì (2004) discussed the importance of ijärah in financing a project, particularly șukūk al-ijārah in investment and development of the economy of a country. He explained that the government, public companies, and Islamic banks can issue șukük al-ijärah in order to provide job opportunities for citizens, thereby enabling the fund owners to invest their funds in projects that are of benefit to the people. This is because most types of șukuk al-ijärah preserve the underlying asset which makes the șukūk transaction fully Shariah-compliant and this makes the șukūk certificates tradable in the Islamic capital markets. He further discussed the types of sukūk al-ijārah, as well as their particularities and their flexibility in financing a project. He highlighted the rules and principles of Islamic law in relation to șukuk al-ijärah. His discussion covers the process of issuance, trading and redemption of sukūk al-ijärah, as well as the circumstances of marketing șukük al-ijärah in countries that pioneered the issuance of 
sukūk, such as Malaysia and Bahrain (Al-Samirītī, 2004). A fundamental limitation of his study is that he did not discuss the application of third party guarantee in șukük al-ijärah, which is a crucial issue in the structuring of this type of șukük.

Similarly, Koutoub (2004) discussed the importance of sukūk al-ijärah for increasing and developing the capital of investment, as well as the concept of șukük al-ijärah in financing a project. Furthermore, he discussed the concept of securitization in the economy and further explains the forms of sukūk al-ijärah according to its subscriptions or offering and rules of issuance and circulation of the șukūk (Koutoub, 2004). He concludes his analysis by giving suggestions for contemporary financial institutions and corporations to innovate new forms of sukūk in order to face the increasing challenges in the financial system (Koutoub, 2004). His work is useful in highlighting the concept of șukük al-ijarah in Islamic law, the economic aspects of it, as well as the concept of securitization of șukūk al-ijärah. He did not however extend his discussion to guarantee of this type of șukukk. This leaves a significant gap for further studies in this regard. A similar literature gap is also contained in related work of al-Taskhīrī \& al-Mablagī (2004) which also comprehensively discussed șukūk al-ijärah without any reference to third party legal guarantee.

Hammād (2004) discussed the economic and financial benefits of șukük al-Ijärah and referred to the views of some economists and researchers on the relevance of this type of șukük in formulating the monetary policy of a country. Thus, the government of a country needs financial stocks to ensure price stability for sound and robust monetary policies. In such a way, șukukk al-ijärah is suitable for financing a huge number of projects that a country needs to finance which will be of benefit to the public. In addition, șukukk al-ijärah can be used as a financing instrument for Islamic banks to cater for their liquidity needs. They can issue șukük al-ijärah in proportion to finance a leased asset that they will manage in order to retrieve what they have expended, so as to reuse the funds to finance other projects (Hammād, 2004: 13-51). In addition, the financial market and the money market need various existing and perpetual financial stocks, especially financial stocks that have regular revenues and less risk so that the market can return to those stocks in order to specify the revenues of higher level of risk which appears normally in the stocks. Furthermore, he discussed the contemporary practice of șukük al-ijärah in Bahrain and revealed that the government guaranteed the original price of this șukük at the conclusion of issuance. This included continuous lease of the $s u k \bar{u} k$ asset during the period of the lease stated in the prospectus. His discussion covers the views of scholars on this type of șukukk. However, he did not discuss whether the government's guarantee for this șukukk al-ijärah is permissible in Islamic law or not and how it was carried out. His work would be very useful for this study because it is on sukük al-ijärah and its contemporary practice, and it provides a good basis for the discussion on the application of third party guarantee for the șukukk.

\subsection{The Use of Third Party Guarantee in Structuring Șukuk}

While the previous studies reviewed above have discussed the dynamics of specific types of $s u k u k$, they have not specifically addressed the use of third party guarantee in structuring șukuk. This subsection explores relevant literature on the use of third party guarantee in some speicifc types of șukūk. Najadāt (2007) and Ibrāhīm (2004) discussed the concept of contract of guarantee from the Sharīah and civil law points of view. Their separate but related discussions contain the issue of guarantee in sukuk al-mudärabah, and highlight resolution no. 30/5/4 of the Islamic Fiqh Academy pertaining to voluntary third party guarantee in șukuk al-mudārabah. Similarly, al-Salāmī (1988) and Hasān (1988) discussed the structure of șukūk al-mudärabah and the application of third party guarantee. They highlighted the opinions of jurists on guarantee of principal amount of șukük al-mudärabah and concluded that it is permissible for the government to guarantee the principal amount or a portion of profit in order to encourage investment. Their discussion favours the permissibility of voluntary third party guarantee so as to promote and develop the economy of a country.

From a different but related perspective, al-Mīn (1988) discussed the forms of sanadāt al-muqäradah (which is another name for șukūk al-mudārabah), as offered by the Jordanian Ministry of Endowment based on the extant civil law in the country. He concluded that the government of Jordan may guarantee the sanadät al-muqäradah and return to the mudārib for reimbursement. However, one may argue that this governmental legal guarantee for the capital of the investment is impermissible in Islamic law because it is in reality a guarantee of the investee (mudārib) for the investment account which jurists unanimously considered as impermissible. In addition, he discussed the maturity period of sanadāt and highlighted the way these sanadät are transacted and the way in which the issuers refund the money to the investors at the maturity of the period. Apart from his analysis on sanadat almuqāraḍah, al-Mīn (1988) also discussed sanaḍāt al-istithmār (investment certificates) generally as practiced in Jordan. One important aspect of his analysis is the discussion on the rules of mudarrabah and circumstances where the mudarrib will be liable for guarantee of a loss caused by failure of the investment. He concluded the study that naming this type of sukūk as sanadāt al-muqäradah does not make such investment product lawful since he 
believed the investment certificates were transacted is not Sharī'ah-compliant because they are based on ribā (Manī, 1988).

Conversely, Hamūd (1988) contended that sanadāt al-muqāradah is a new form of investment which facilitates investment opportunities, exchange of transactions and a means of encouraging investments in a project that will serve the interest of the public. He argued that the sanadät of financing and certificates of investment which the government issued may be converted to sanadāt al-muqäradah which are in conformity with the principles of Islamic law by specifying the amount of the project. However, investment of those sanadat in the public interest in order to get the benefit from the remaining value of the sanadāt as debt on the issuer or his agent might amount to a transaction that contravenes the principles of Islamic law, because the debtor may be requested to pay additional money to the creditor. He added that it is permissible for the government to undertake to buy the sanadāt al-muqāradah that may be issued by institutions such as Endowment Institution and Public Corporations, as this will encourage the investors to participate in the development of the economy. It will also attract saving funds to be invested in the projects of a country. His work mostly focuses on the investment of șukuk and its forms in financing a project but it is very useful in understanding the dynamics of the commitment of the government to pay back the price of sukūk al-mudärabah at the maturity of the period.

Al-'Abādī (1988) examined sanadāt al-muqāradah and the difference between them and other types of sanadāt. He also discussed the importance of sanadāt al-muqäradah and their role in the development of the economy in contemporary Muslim societies. He argued that the benefit of sanadāt al-muqäradah will be fully realised when they are used to finance big projects and long-term investment, which are vital to the growth of the economy of any country. This type of investment is Sharí' ah-compliant as it is free from ribā. Therefore, those sanadāt can be considered an alternative to conventional bonds, which are based on riba $\bar{a}$. His discussion also covered the way and manner in which the jurists legalised these types of sanadät al-muqäradah. The other issues discussed in his work include the relationship between the subscribers and issuers of those sanadät and also when the mudārib will be liable for any loss incurred in the investment. He reiterated that the jurists unanimously agree that a mudārib cannot guarantee any loss from the mudärabah investment, unless it is due to negligence or a transgression.

\section{Charging Fee in Third Party Guarantee in Sukük Transactions}

It is worthwhile to assert that contemporary scholars discussed legal guarantee in general terms in the relationship between the guarantor and guaranteed party. They also analysed third party guarantee in financial transactions as applicable to contemporary Islamic capital market. Based on current knowledge, it seems that only a few scholars have discussed the application of third party guarantee in șukūk al-ijārah and șukūk al-mudārabah. However, for sukūk al-istișna $\bar{a}^{\prime}$ there are some studies that discuss this issue such as Kamil (2007). Furthermore, it can be observed that both classical and contemporary scholars agree that guarantee is a voluntary task in which the guarantor should not take any fee from it, with the exception of the following scholars: Hammād (2001), Al-Zuhailī (2003), and the ruling of Shariah Advisory Council of the Malaysian Securities Commission.

Hammād (2001) discussed third party guarantee and concluded that it is permissible to charge a fee. He highlighted the views of the jurists on the fee that is taken on guarantee and contended that the opinion of jurists who disallow the taking of fee on guarantee is invalid. He concluded his analysis that charging a fee on guarantee may be allowed with certain conditions, among them being that it is permissible for the guarantor to charge a fee for a legal guarantee if he has paid or settled the debt immediately on behalf of the principal debtor. This is because the guarantor had paid the debt on the spot without any delay which can be considered as a service which he performed on behalf of the principal debtor. Therefore, the guarantor has the right to charge a fee for that service. He however argued that if the guarantor paid the debt on deferred payment, it is impermissible for him to charge a fee on the guarantee. On his part, Al-Zuhailī (2003) examined the issue of guarantee in financial matters and the way it is being applied in modern commercial transactions. He emphasised that it is permissible to charge a fee for a legal guarantee in order to meet the necessity, if the principal could not find a voluntary guarantor. Furthermore, the Shariah Advisory Council of the Malaysian Securities Commission in its $36^{\text {th }}$ meeting held on $6^{\text {th }}$ February 2002, resolved that charging a fee for a third party legal guarantee is permissible (Securities Commission Malaysia, 2002). It might be appropriate for Sharī'ah scholars to consider each of the fourteen șukūk recognised by AAOIFI in their own regard. The nature of each șukuk transaction will determine whether it is appropriate to charge a fee for a third party legal guarantee or not. 


\section{Conclusion}

In conclusion, it can be observed that most of the existing literature on this theme focuses on guarantee in general. Classical and contemporary jurists agree that guarantee should be done voluntarily, with the exception of Wahbah al-Zuhailī, Nazīh Hammād and the Shariah Advisory Council of Malaysian Securities Commission. Even though the literature on sukūk generally has mushroomed over the last decade, much attention has not been given to the application of third party guarantee in Islamic capital market, particularly in șukūk transactions. Therefore, there is a crucial need to conduct further research on this subject in order to determine a clear position on Sharī'ah on the issues raised.

Therefore, it is appropriate for future research to examine the application of third party guarantee in șukūk alijārah, șukūk al-mud̄ârabah and șukūk al-istișna ' in leading Islamic finance jurisdictions, particularly in Malaysia and Bahrain. In this regard, the extent of application of third party guarantee in each of the șukūk structures needs to be closely examined.

Finally, the preliminary findings from the literature surveyed include: the use of third party guarantee is permissible in Islamic law; even though such legal guarantee is permissible, it should be done voluntarily; no fee should be charged for a legal guarantee when the concept is used in structuring șukūk products. However, for șukūk

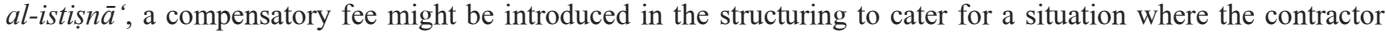
fails to deliver the subject matter of the contract based on the contractual due date which has led to some sort of damage on the part of the contractee.

\section{References}

Al-Zarqa', Mustafa Ahmad (1997). Al-Madkhal al-Fiqh al-Am. Damascus: Dar al-Qalam.

Abdel-Khaleq, A. H., \& Richardson, C. F. (2006). New horizons for Islamic securities: Emerging trends in Sukuk offerings. Chicago Journal of International Law , 7 (2).

‘Al-Bādī, A. D. (1988). “Sanadāt al-muqāraḍah” Majallah Majma'a al-Fiqh al-Islāmī, vol.3, no. 4 session no.4. Jeddah: Majma“ alFiqh al-Islāmī.

Al-Bahūtī, M. Y. (2003). al-Raw d al-Murbi 'bi Sharḥ Zād al-Mustaqni', Taḥīi Khalīl 'Amrūt

al-Manșūr, $1^{\text {st }}$ edition. Beirut: 'Ālam al-Kutub.

Al-Khatīb, M. S. ( n.d). al-'Iqnā' fì Hali al- Fāz Abì-Shajā'. vol 2. Jakarta: Dār al-Fikr.

Al-Haitamī, S. A. A. (2001). Tuḥfah al-Muhtāj bi Sharḥ al-Minhājj. wa huwa Sharḥ alā Kitāb Minhāj al-Ṭālibīn fī Fiquh al-Imām alShāfíīi, li Abī Zakariyā Muhyī al-Dīn Yaḥyā bin Sharaf al-Nawawī, Ḍabaṭahu wa Șaḥahahu wa Kharraja Āyātuhu, 'Abd Allāh Muhmūd Muhammad 'Umar. vol. 2, $1^{\text {st }}$ edition. Beirut: Dār al-Kutub al-Ilmiyyah.

Al-Yamanī, A. Y. A. (2000). al-Bayān fì Mudhhab al-Imām al-Shāfi 'ī. I'tanā bihi, Qāsim Muhammad al-Nūrī, vol. 6 . al-Riyāḍ: Dār al-Minhāj.

Al-Dasūqī, M. A. A. (2003). Hāshiyat al-Dasūqì 'alā al-Sharhị al-Kabīr. Abū al-Burkāt Ahmad bin Muhammad al-'Adawī Ashahīr bi al-Dardīr, wa bi al-Hamish Taqrīrāt al-Muhaqiq, Muḥammad bin Aḥmad bin Muḥammad. Kharraja Āyātuhu wa Āhādīithahu, Muhammad 'Abd Allāh Shāhīn. vol. 4. Beirut: Dār al- Kutub al-'Ilmiyyah.

Al-Dasūqī, S. M. A. (1996). Hāshiyah al-Dasūqī 'alā al-Sharh al-Kabīr. vol. 3. Beirut: Dār al-Kutub al-'Iimiyyah.

Al-'Ị̣sā'ī, A. H. A. (1995). Tabyin al-Masālik Sharh. Tadrīb al-Sālik 'Ilā 'Aqrab al-Masālik, Sharḥ al-Shaikh Muhammad alShaibānī bin Muhammad bin Ahmad al-Shanqīị̄i al-Murītānī, vol. 4, $2^{\text {nd }}$ edition. Beirut: Dār al-Gharb al-Islāmī.

Al-Sarakhsī, A. M. A. (2001). Kitāb al-Mabsūt, vol. 19 Taḥī̄ Abī Abd Allāh

'Abd al-Raḥamān bin Muhammad bn Sulaimān al-Kalībūīi. 1998. Majma' al-Anhar fì Sharh Multaqā al-Abuhr vol. 3 Beirut: Dār al-Kutub al-'Ilmiyyah.

Al-Humāmah Niẓām wa jamā'at min al-Hind al- 'llām. (2000). Fatāwā al-Hindiyyah vol.4, vol.5 Beirut, Dār al- Kutub al'Ilmiyyah.

'Ali al-Khafîf. (n.d). al-Damān fì al-Fiqh al- Islāmī vol. 2, Cairo: Dār al-Fiqr al-Islāmī.

'Ali Aḥmad al-Sālūs. (1986). al-Kafālah wa Tațbiqātuhā al-Mu'șirah. Kuwait: Maktabat al-Falāh

'Ali Jamāl Al-Dīn 'Awaụ. (1991). Khițābāt al-Ḍamān al-Mașrafiyyah. Cairo: Dār al-Nahụah al-'Arabiyyah.

Al-'Allamah Abī Maḥammad bin Ghānim bin Maḥammad al-Baghdādī. (1999). Majma' al- Damānāt vol. 2. Cairo: Dār al- Salām.

'Abd al-'Azīz al-Khayāṭ and Aḥmad Șabḥ̄ al-'Ayādī. (2004). Fiqh al-Mu'āmalāt wa Siyag al- Istithmār (Jordan: Dār alMutaqadimah.

Al-Dasūqī. (2003). Hāshiyat al-Dasūqī 'alā al-Sharh al-Kabīr,Taqrīrāt al-Muḥaqiq, Muḥammad bin Aḥmad bin Muḥammad. Kharraja Āyātuhu wa Āhāeīithahu, Muhammad 'Abd Allāh Shāhīn, vol. 4 Beirut: Dār al- Kutub al-'Ilmiyyah.

'Adil Aḥmad Abdul mawjūd, Muḥammad Mujdī Sarūr Bā salūm, Aḥmad Isā Ḥuseini al-Mu'asarāwī, Aḥmad Muḥammad 'Abdul al-'Ali, Ḥusein 'Abd al-Raḥmān Aḥmad, Badwī 'Alī Muḥammad Sayid, Muḥammad Aḥmad 'Abd Allāh and Ibrahīm Muhammad 'al-Bāqī. (2002). Takmilat al-Mujmū', Sharh al-Muhazzab, , vol.7, vol. 14 . Beirut: Dar al-Kutub al-'Ilmiyyah.

Al-Kāsānī, 'Abū Bakar bin Mas'ūd al-Ḥanafī. ( 2005). Badā' $i$ ' al-Sanā'i' fí Tartīb al-Sharā 'i' Dabata Nașhu wa Haqaqahu, Muhammad Muhammad Tāmir, vol. 7. Cairo: Dār al-Hadīth.

Al-Nawawī ,'Abū Zakriyā Yahyyā bin Sharaf al-Dimashqī. (2000)..Raw ḍah al-Ṭālibìn, Ḥaqaqahu wa Kharaja 'hādīthahu wa 'allaqa 'alayhi, Fouwād bin Sirāj 'Abdul-Ghaffār 'Abū 'Abd al-Raḥmān, vol.4. Egypt: al-Maktabah al-Tawfĩqiyyah. 
'Akmal al-Dīn bin Muḥammad bin Muḥammad bin Mạ̣mūd al-Bābartī al-Ḥanafī. (2007). al-'Ināyah Sharh al-Ihidāyah $1^{\text {st }}$ edition, vol.5 . Beirut: Dār al-Kutub al-'Ilmiyyah.

'Abd al-Sattār 'Abū Ghuddah. (1998). al-Ijārah $1^{\text {st }}$ edition. Jeddah : Majmū'ah Dallah al-Barkah.

'Abd al-Wahāb Ibrāhīm 'Abū Sulaymān. (1992 ). 'Aqd al-Ijārah Mașdar Min Maṣādir al-Tamwīl al-Islāmī, Dirāsah Fiqhiyyah Muqāranah $1^{\text {st }}$ edition. Jeddah : IRTI.

‘Alī Muhyī al-Dīn al-Qarah Dāghī. (2004). ”Sukūk al-ijārah Khașā’iṣuhā wa Ḍawābituhā” in Majallah Majma 'a al-Fiqh al-Islamī vol. 2, no.15. Jeddah: Majma' al-Fiqh al-’ Islamī.

‘Abd Allāh bin Sulaimān bin Manī'.(1988). "Sanadāt al-Muqāraḍah wa Sanadāt al-Istithmār” in Majallah Majma'a al-Fiqh alIslāmī, vol 3, no. 4 session no.4. Jeddah: Majma'a al-Fiqh al-Islāmī,.

Al-Sayyid Muḥammad Aḥmad al-Samirītī,. (2004). "Sukūk al-Ijārah” in Majallah Majma'a al-Fi'qh al-Islāmī, vol 2, no. 15. Jeddah: Majma' al-Fi'qh al-Islāmī..

Aḥmad Ibrāhīm Bek, al-Mu 'āmalāt al-Sharī'ah al-Māliyyah (Cairo: Dār al- Anșār 1936), 183-198.

Al-Qarāiī,Shihābu Al- Dīn Abī al- Abās Ahmad bin 'Abd al-Rahamān al-Ṣanhānī .(2001). al-Dhakhīrah fì Furū' al-Mālikiyyah vol. 6, vol. 9, (Beirut: Dār al-Kutub al-'Ilmiyyah.

'Alī Ḥaidar. (2003). Duraru al-Hukkām, Sharh Majallah al-'Ahkām, Ta'rīb, al-Muhāmī Fahmī al-Husainī, vol.1 Beirut: Dār alJalìl,

Fres-Felix, M. L. (1991). Deposit Insurance Schemes: Its Nature, Role and Issues. Kuala Lumpur: The South East Asian Central Banks Research and Training Centre.

Hammād, N. K. (2001). Qậāyā Fiqhiyyah Mu'șarah fí al-Māl wa al-Iqtișād. $1^{\text {st }}$ edition. Beirut: Dār al-Shāmiyyah.

Hassan, M. K., Kayed, R. N., \& Oseni, U. A. (2013). Introduction to Islamic banking and finance: principles and practice. Essex, England: Pearson Education Limited.

Henkel, C. (2014). Personal Guarantees and Sureties between Commercial Law and Consumers in the United States . American Journal of Comparative Law, 62 (1).

Husnī 'Abd al-Samī' Ibrāhīm. (2004). Mawqif al-Fuqhā' min Damāni al-'amwāl(Egypt: Maktabatu Nānasī.

Ḥussein Ḥāmid Ḥasān.. (1988). "Damān Ra'as al-māl aw al-ribih fī Șukūk al-Muḍārabah aw Sanadāt al-Muqāradah ", in Majallah Majma' al-Fiqh al-Islāmī vol.3, no.4, session no. 4. Jeddah: Majma' al-Fiqh al-Islāmī..

Hasan 'Abd Allāh al-Mīn. (1988). "Sanadāt al-Muqāraḍah wa Sanadāt al-Istithmār”" in Majallah Majma ' al-Fiqh al-Islāmī, vol 3, no.4 session no.4. Jeddah : Majma'a al-Fiqh al-Islāmī.

Ibn Qudāmah. (n.d.). al-Mughnī, vol 4. al-Riyāḍ: Muktabātu al-Riyāḍ al-Hadīthah.

Ibn al-Najār, T. M. A. (1996). Muntahā al-Irādāt fì Majma' al-Muqni' ma' al-Tanqīhwa Ziyāiāt, Tahqīq 'Abd al-Ghanī 'Abd alKhāliq, vol.1, $2^{\text {nd }}$ edition. Beirut: 'Ālam al-Kutub.

Ibn al-Sā 'Ātī al-Hanafĩ. 2005. Majma' al-Bahrain wa Multaqā al-Nīrain fí al-Fiqh al-Hanafì, Dirāsaah wa Tahqīq Ilyās Qabalān . Beirut: Dār al-Kutub al-Ilmiyyah.

Ibn al-Hamām, Kamāl al-Dīn Muhammad bin 'Abd al-Wāhid al-Siwāsī thumma al-Sakandarī, al- al-Hanafī. (1995). Sharh Fatahu al-Qadīr, alā al-Hidāyah Sharh Bidāyah al-Mubtadī, Burhān al-Dīn 'Alī bin Abī bakar al-Marghānī, 'Allaqa 'alaihi wa kharaja āyātuhu wa ạ̣ādīthahu , 'Abd al-Razāq ghālib al-Mahadī, vol. 7 Beirut: Dār al-Kutub al-Ilmiyyah.

Ibn Rushd, Muḥammad bin Aḥmad al-Qurțubī. (1985). Bidāyat al-Mujtahid wa Nihāyat al-Muqtașid vol. 2. Beirut: Dār- alMa'rifah.

Ibn al- Sā 'atī, Muẓafarar al-Dīn Aḥmad bin 'Alī bin Tha'alab, al-Ḥanafī. (2005. Majma 'a al-Bahraini wa Multaqā al-Nīraini fí alFiqhi al- Hanafi Beirut: Dār al-Kutub al-Ilmiyyah.

Ibn Qudāmah, 'Ảbd Allāh bin Aímad.(n.d) al-Mughnī vol. 4, vol. 6 Beirut:'Alam al-Kutub

Koutoub Mustapha Sano.. 2004). "Sukūk al-Ijārah” in Majallah Majma 'a al-Fiqh al-Islāmī̄, vol 2, no.15 .Jeddah: Majma'a alFiqh al-Islāmī..

Kamil, W. A. (2007). Islamic Participatory Contracts: Mushārakah and Mud̦ārabah (Structuring Sukūk. paper presented at Workshop on detailed Structuring of Islamic Securities. Organized by Islamic Banking and Finance Institute Malaysia 27 October 2007. Kuala Lumpur: Islamic banking and Finance Institute.

Kāmil Musā. (2008). Ahkāmu al-Mu 'āmalāt. Beirut: Muasasatu al-Risālah Nāshurūn.

Madkūr, Muḥammad Salām. (1984). 'Aqd al-Ijārah fì al-Fiqh al-Islāmī al-Muqārin $1^{\text {st }}$ edition. Cairo: Dār al-Nahḍah al'Arabiyyah.

Majma‘ al-Fiqh al-'Islamī.( 2004). Majallah Majma' al-Fiqh al-'Islamī, vol. 2, no. 15 Resolution no. 137/3/15. Jeddah: Majma'a al-Fiqh al-' Islamī.

Maurer, B. (2010). Form versus substance: AAOIFI projects and Islamic fundamentals in the case of sukuk. Journal of Islamic Accounting and Business Research , 1 (1).

McMillen, M. J. (2006). Islamic capital markets: developments and issues. Capital Markets Law Journal , 1 (2).

Muhammad Mahamūd al-'Ajalūnī. (2008). al-Bunūk al-Islāmiyyah wa Aḥkāmuhā wa Mabādi'ihā wa Taṭbīqātuhā al-Musrafiyyah. Jordan: Dār al-Muysarah.

Muhammad Najadāt, Damān al- 'Aqad. (2007). Damascus : Dār al-Maktabī.

Muḥammad al-Mukhtār al-Salāmī. (1988). "Sanadāt al- Muqāraḍah wa Sanaḍat al-Tanmiyyah wa Istithmār" in Majallah Majma 'a al-Fiqh al-Islāmī, vol.3, no.4, session no.4 . Jeddah: Majma‘ al-Fiqh al-Islāmī.

Muhammad Ḥasan Ismā‘īl al-Shāfi'‘ī, Qaddama Lahu Kamāl Abd al-'Az̄ìm al-‘Anānī, vol.19. Beirut: Dār- al-Kutub al-'Ilmiyyah.

Nazīh Kamāl Hamād. ( 2004). "Sukūk al-Ijārah” in Majallah Majma ' a al-Fiqh al-Islāmī, vol. 2, no. 15. Jeddah: Majma“ a alFiqh al-Islāmī..

Rafīq Yūnus al-Mișrī. (2009). Buhūth fì al-Mașārif al-Islāmiyyah. Syria: Dār al-Maktabī

Securities Commission Malaysia (2002). Resolutions of Securities Commission Sharīah Advisory Council. $1^{\text {st }}$ edition. Kuala 
Lumpur: Securities Commission.

Sāmī Ḥasan Hamūd. (1988). "Tașwīr Haqūqat Sanadāt al-Muqāraḍah wa al-Firq baynahā wa bayna Sanadāt al-tanmiyyah wa Shahad̄àt al-Istithmār wa al-Firq baynahā wa bayna al-Sanadāt al-Ribawiyyah” Majallah Majallah al-Fiqh al-Islāmī. vol 3. no 4, session no. 4. Jeddah: Majma‘ al-Fiqh al-Islāmī.

Sulaim Rustam Bāz al-Lubnānī. (1920).Sharḥ al-Majallah, vol. 1, $3^{\text {rd }}$ edition. Beirut: Dār al-Kutub al-Ilmiyyah.

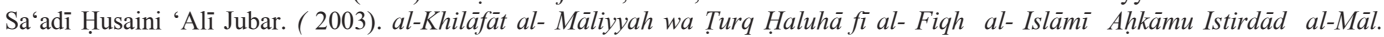
Jordan: Dār al-Nafāis.

The Majallah Ahkām, al-Adliyyah and complete code on Islamic Civil Law, translated by C.R. Tyser, B.A.L. (1980). Lahore: Law Publishing company.

'Ulaish, A. M. (2003). Minaḥu al-Jalīl Sharḥ 'alā Mukhtașar al-'Allāmah Khalīl, ma' Ta'līqāt min Tashīl Minaḥu al-Jalīl, Dabatahu wa Șahahạahu, 'Abd al-Jalīl 'Abd al-Salām, vol.6, $1^{\text {st }}$ edition. Beirut: Dār al-Kutub al-Ilmiyyah.

Wahbah al-Zuhailī. (2003). al-Fiqh al-Islāmī wa al-Dillatuhu. vol. 2. Damascus: Dār al-Fikr. al-Khatīb, M. S. (n.d.). al-'Iqnā' fì Hali al- Fāz Abī-Shajā' vol 2. Jakarta: Dār al-Fikr.

Wahbah al-Zuhailì. (2006). Nazariyyat al-Damān aw Ahkām al-mas'ūliyyah al-Madniyyah wa al-janā'iyyah fì al-Fiqh al-'Islamì Dirāsah Muqāranah. Beirut: Dār al-Fikr al-Mu'āsir.

Wahbah al- Zuhailī. (1998). Nazariyyat al-Damān. Damascus: Dār al-Fikr.

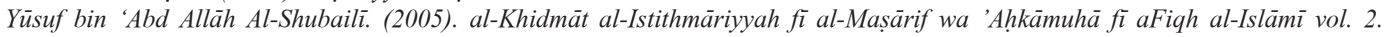
Dammam: Dār Ibn al-Jawzī. 